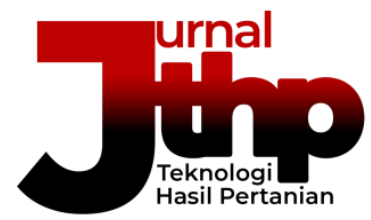

Jurnal Teknologi Hasil Pertanian. 14(1), 44-61

URL: https://jurnal.uns.ac.id/ilmupangan/article/view/44719

DOi: https://doi.org/10.20961/jthp.v14i1.44719

ISSN 1979-0309 (Online) 2614-7920 (Print)

\title{
PENGARUH EKSTRAK JAMBU BIJI MERAH (Psidium guajava Linn) TERHADAP KUALITAS DAGING SAPI DALAM PROSES CURING
}

\author{
EFFECTS OF RED GUAVA EXTRACT (Psidium guavaja Linn) ON BEEF QUALITY IN THE \\ CURING PROCESS
}

\author{
Aditya Haradito, Rohula Utami, dan Asri Nursiwi \\ Program Studi Ilmu Teknologi Pangan, Fakultas Pertanian, Universitas Sebelas Maret \\ Email: aharadito@student.uns.ac.id
}

Diserahkan [6 Oktober 2020]; Diterima [14 Februari 2021]; Dipublikasi [20 Februari 2021]

\begin{abstract}
Curing is a method that can be used to maintain the quality of beef. The curing method uses nitrate and nitrite compounds, which have useful roles in the curing process. However, those compounds have a side effect on the body if consumed continuously, which causes cancer disease (carcinogenic). This harmful carcinogenic property can be controlled by the addition of ascorbic acid. Ascorbic acid is commonly found in several fruits, one of which is red guava (Psidium guajava L). Therefore, this study aims to find out the most optimal addition of red guava extract in maintaining the beef qualities with curing treatment on the parameters of water content, $\mathrm{pH}$, whc, texture, color, ascorbic acid, and nitrite residue. This study was conducted using a Completely Randomized Design with the various concentration of red guava extract (0\%-5\%) and observed at soaking times of 0,2, 4, and 6 days. The analysis was performed by twice of sample repetition and analysis repetition. The results of the analysis were statistically analyzed by One Way ANOVA continued with the DMRT test if the results were significantly different $(\alpha=0.05)$. Based on the results of the study, the higher of concentration in red guava extract, the $\mathrm{pH}$, water content, whc, $b^{*}$ color, $a^{*}$ color, nitrite residue were smaller while the hardness, springiness, cohesiveness, $L^{*}$ color, $a^{*}$ color, the ascorbic acid content in curing were higher. The chosen treatment due to the test parameter in this study was the addition of $4 \%$ concentration in red guava extract in the curing process with 2 days soaking times.
\end{abstract}

Keywords: ascorbic acid; beef; red guava extract

\section{ABSTRAK}

Curing merupakan metode yang dapat digunakan untuk menjaga kualitas daging. Penggunaan metode curing menggunakan senyawa nitrat dan nitrit, dimana kedua senyawa itu memiliki peran yang menguntungkan pada proses curing, namun senyawa itu memiliki efek samping apabila dikonsumsi tubuh secara terus-menerus yaitu memicu penyakit kanker (karsinogenik). Sifat karsinogenik yang berbahaya ini dapat dikendalikan dengan penambahan asam askorbat. Asam askorbat umumnya terdapat pada beberapa buah, salah satunya buah jambu biji merah (Psidium guajava L). Penelitian ini bertujuan untuk mengetahui penambahan ekstrak jambu biji merah yang paling optimal dalam mempertahankan kualitas daging sapi dengan perlakuan curing pada parameter kadar air, $\mathrm{pH}$, whc, tekstur, warna, asam askorbat, dan residu nitrit. Penelitian ini dilakukan dengan menggunakan Rancangan Acak Lengkap dengan variasi konsentrasi ekstrak jambu biji merah $(0 \%-5 \%)$ dan diamati pada waktu perendaman 0,2, 4, dan 6 hari. Analisis dilakukan dengan dua kali ulangan sampel dan dua kali ulangan analisis. Analisis hasil secara statistik dengan One Way ANOVA, apabila hasil yang didapatkan beda nyata, maka dilanjutkan dengan uji DMRT $(\alpha=0,05)$. Berdasarkan hasil penelitian semakin tinggi konsentrasi ekstrak jambu biji merah akan menyebabkan nilai $\mathrm{pH}$, kadar air, whc, warna $\mathrm{b}^{*}$, residu nitrit semakin kecil, sedangkan nilai hardness, springiness, cohesiveness, warna $\mathrm{L}^{*}$, warna $\mathrm{a}^{*}$, kandungan asam askorbat pada daging curing semakin besar. Perlakuan terpilih berdasar parameter pengujian terdapat pada penambahan konsentrasi ekstrak jambu biji merah pada proses curing sebanyak 4\% dengan lama perendaman 2 hari.

Kata kunci : asam askorbat; daging sapi; ekstrak jambu biji merah 
Saran sitasi: Haradito, A., Utami, R., \& Nursiwi, A. (2021). Pengaruh Ekstrak Jambu Biji Merah (Psidium guajava Linn) terhadap Kualitas Daging Sapi dalam Proses Curing. Jurnal Teknologi Hasil Pertanian, 14(1), 44-61. https://doi.org/10.20961/jthp.v14i1.44719

\section{PENDAHULUAN}

Daging menjadi salah satu sumber bahan makanan yang memiliki beraneka ragam kandungan asam amino (Forrest, 1975). Menurut Soeparno (2015), daging menjadi salah satu sumber gizi bagi manusia seperti lemak, vitamin dan mineral, dengan kandungan yang terdiri atas $75 \%$ air, $18 \%$ protein, $4 \%$ protein yang bisa larut (termasuk mineral) serta 3\% lemak. Menurut Diarmita (2018), konsumsi daging per kapita di Indonesia naik 25,73\% dari tahun $2016 \mathrm{ke}$ tahun 2017, dan untuk konsumsi daging sapi per kapita naik 12,50\% dari tahun 2016 ke tahun 2017.

Daging menjadi salah satu sumber bahan makanan yang memerlukan proses pengawetan karena daging mudah mengalami kerusakan. Faktor penyebab kerusakan daging diantaranya yaitu kerusakan yang disebabkan oleh mikroorganisme dan kondisi penyimpanan tidak tepat yang berkaitan dengan suhu dan kelembaban. Kerusakan yang disebabkan oleh mikroorganisme dapat menyebabkan pembusukan, perubahan warna, perubahan tekstur dan terbentuknya eksudasi cairan (Aidani, 2014). Beberapa kerusakan yang ditimbulkan oleh mikroorganisme dapat dikurangi dengan cara menghentikan pertumbuhan mikroorganisme dalam daging menggunakan perlakuan khusus, pengolahan, dan penambahan pengawet (Purnomo, 2013). Selain faktor mikroorganisme, kondisi penyimpanan daging seperti suhu dan $\mathrm{pH}$ juga dapat mempengaruhi kualitas daging (Xing, 2018). Daging yang mudah mengalami kerusakan membutuhkan penanganan tambahan untuk menjaga kualitas, cara pengawetan atau perlakuan tambahan. Pengawetan dan perlakuan tambahan pada suhu rendah, pembekuan, pengeringan dan radiasi biasa dilakukan, namun ada efek samping yang dapat merubah tekstur daging karena daging mengalami pengerutan, merubah sifat kimia, organoleptik dan akan merubah warna dari daging segar.
Daging segar memiliki warna merah keunguan tetapi warna permukaan daging akan berubah menjadi warna merah terang dan jika dibiarkan semakin lama dan terkontaminasi akan berubah menjadi kecoklatan. Terbentuknya warna coklat menjadi tanda bahwa daging telah mengalami penurunan kualitas dan berpengaruh terhadap daya terima daging. Curing salah satu metode yang dapat dipakai untuk menjaga warna merah daging dan menjadi proses awal terhadap daging segar sebelum menggunakan proses pengawetan dan tahap pengolahan selanjutnya (Astawan, 1989). Curing biasanya terdiri dari $\mathrm{NaCl}$ (garam), Na-nitrit, Na-nitrat, gula, dan komposisi-komposisi lainnya. Menurut Cassens (1978), penggunaan nitrit dalam proses curing dapat membuat rasa yang khas, menstabilkan warna merah daging, sebagai antimikrobia, dan memperlambat terjadinya bau tengik. Warna merah pada daging merupakan reaksi penguraian nitrit menjadi nitrit oksid. Nitrit oksid selanjutnya bereaksi dengan mioglobin (pemberi warna merah daging) dan menghasilkan senyawa nitrosomioglobin.

Curing daging memakai nitrit yang jika penggunaan berlebihan akan mengakibatkan bahaya bagi tubuh manusia (Forrest, 1975). Nitrit adalah prekusor dari nitrosamin yang bersifat karsinogenik dengan cara bereaksi dengan senyawa amina. Nitrosodimetilamin merupakan hasil reaksi nitrit yang dapat menyebabkan resiko kanker lebih berbahaya daripada nitrosopirolidin (Soeparno, 2015). Proses curing pada daging membutuhkan pengendalian yang benar karena sifat residu nitrit yang berbahaya, dengan penambahan asam askorbat merupakan salah satu cara pengendalian residu nitrit. Asam askorbat sanggup mempercepat pembentukan nitrit oksida atas nitrit sebab asam askorbat berfungsi sebagai reduktor yang bisa membagikan elektron dalam nitrit sehingga terbentuk nitrit oksida (Forrest, 1975). Asam askorbat akan mempercepat dekomposisi ion nitrit ke nitrit oksid yang nantinya hendak bereaksi beserta mioglobin (penyumbang 
corak merah daging) (Soeparno, 2015). Selain itu, asam askorbat adalah inhibitor (penghambat) kuat yang dapat menurunkan pembentukan nitrosamin. Penambahan asam askorbat dapat menghambat diskolorasi pada permukaan potongan beef (Mancini, 2008).

Menurut Soeparno (2015), kandungan nitrit yang terdapat pada proses curing tidak melebihi 200 ppm sedangkan nitrat tidak diperbolehkan melebihi 500 ppm. Oleh sebab itu penggunaan nitrat atau nitrit harus memperhatikan batas aman penggunaan untuk menurunkan resiko bahayanya. Menurut Soeparno (2015), penggunaan nitrat bisa dikurangi pada proses curing, hal ini karena penggunaan nitrit sudah mampu mengoptimalkan proses curing tanpa ada nitrat. Menurut Tiso (2015), walaupun nitrat bisa dikonversi menjadi nitrit oleh bakteri, namun pada konsentrasi yang berbeda akan mempengaruhi pembentukan nitrit, amonia dan nitrit oksida, selain itu pula keberadaan nitrat sebanyak $5 \mathrm{mM}$ akan membantu menginduksi nitrit dan amonia pada bakteri E. coli dan Lactobacillus. Menurut Govari (2015), nitrat tidak memiliki kemampuan terhadap pertumbuhan $C$. botulinum, namun nitrat akan terurai menjadi nitrit sebagian untuk menghentikan laju $C$. botulinum dan sisanya akan membentuk sensorik produk curing daging. Nitrit memiliki kekuatan sebagai antimikrobia dan membuat warna daging menjadi warna merah segar, dengan adanya nitrat yang ditambahkan bisa menjadi antioksidan pada produk daging dan jika kedua bahan ditambahkan sesuai anjuran dapat meningkatkan daya cerna daging pada tubuh manusia (Honikel, 2008). Menurut Karwowska (2020), pengunan tambahan nitrat dan nitit dibutuhkan untuk produk daging yang tidak dimasak, namun jika pada produk olahan daging bisa menggunakan nitrit saja.

Penelitian terdahulu menunjukkan bahwa penggunaan bahan yang mengandung asam askorbat untuk curing dapat meminimalisasi residu nitrit. Ermawati (2008) melakukan penelitian berupa perendaman daging menggunakan sari buah jeruk nipis dengan konsentrasi asam askorbat $6 \%$ selama 6 hari perendaman dan hasil pengujian nilai residu nitrit yang dihasilkan adalah 15,064 ppm. Penelitian lain juga dilakukan oleh Yuniarti (2011) yang memanfaatkan ekstrak daun rosella sebagai asam askorbat dengan konsentrasi ekstrak rosella merah sebesar $7,24 \%$ selama 7 hari menghasilkan nilai residu nitrit 19,537 ppm.

Buah jambu biji merah (Psidium guajava $\mathrm{L}$ ) mengandung vitamin $\mathrm{C}$, vitamin B1, vitamin A, lutein, zeaxanthine, lycopene, fenol, flavonoid, essential oils, saponin, carotenoid, kalsium, fosfor, besi, mangan, magnesium, belerang, dan asam amino (triptofan, lisin) (Pdpersi, 2004). Kandungan asam askorbat jambu biji merah berkisar 87 mg /100 g yang memiliki nilai 2 kali lipat lebih banyak dibandingkan jeruk manis (49 $\mathrm{mg} / 100 \mathrm{~g}$ ) dan memiliki nilai 8 kali lipat lebih banyak dibanding lemon (10,5 mg /100 g) ('Afani, 2016). Buah jambu biji merah memiliki nilai $\mathrm{pH}$ yang rendah yaitu 4,24 (Tampubolon, 2017).

Daging yang direndam pada kondisi $\mathrm{pH}$ rendah dapat menyebabkan perubahan kadar air pada daging karena selama perendaman, daging mengalami penurunan daya ikat air sehingga kandungan air pada daging sapi menjadi berkurang (Soeparno, 2015). Penurunan daya ikat air juga disebabkan oleh pembentukan aktomiosin dan ATP pada saat rigor yang berpengaruh sebesar $2 / 3$ bagian dan 1/3 lainnya disebabkan oleh penurunan $\mathrm{pH}$ (Soeparno, 2015). Menurut Ermawati (2008), eksudasi cairan merupakan salah satu tanda penurunan daya ikat air yang disebut weep pada daging mentah sebelum dibekukan atau pada daging mentah beku yang disegarkan kembali. Hilangnya cairan mengakibatkan penurunan kualitas dan daya terima oleh konsumen. Oleh karena itu, penelitian ini dilakukan untuk mengetahui pengaruh konsentrasi ekstrak jambu biji merah terhadap kualitas dan residu nitrit daging yang diberikan perlakuan curing. Konsentrasi jambu biji merah yang bervariasi diharapkan dapat menentukan perlakuan terbaik dalam pembuatan daging sapi dengan perlakuan curing. Parameter pengujian kualitas daging sapi dengan perlakuan curing yaitu $\mathrm{pH}$, kadar air, WHC, tekstur, warna, kandungan asam askorbat, dan nilai residu nitrit. 


\section{METODE PENELITIAN}

\section{Bahan}

Bahan yang digunakan dalam penelitian ini menggunakan jambu biji merah varietas getas (Psidium guajava L) (umur panen 4 bulan dengan ciri-ciri warna yang mengkilap, hijau kekuningan, bau harum, dan permukaan kulit yang halus), daging sapi PO bagian brisket umur panen 2 tahun, Gula pasir "Gulaku", yang didapatkan dari Pasar Gede, Surakarta. Bahan $\mathrm{NaNO}_{3}$ "Merck", $\mathrm{NaNO}_{2}$ "Merck" didapatkan dari Chemix, Yogyakarta. $\mathrm{NaCl}$ "Merck" didapatkan dari CV Agung Jaya, Surakarta.

\section{Alat}

Alat yang digunakan dalam penelitian ini menggunakan Color Meter TES-135A, CT3 Textre Analyzer, sentrifugator "PLC 3 Gemmy Taiwan 3", oven "Memmert", desikator "Normax", pH meter "AMT-20", statif, buret, waterbath "Memmert", kertas whatman no.42, inkubator "Memmert", dan spektrofotometer UV-Vis "Shimadzu UV1280 ".

\section{Tahapan Penelitian}

\section{Proses curing}

Tahapan awal penelitian ini yaitu membuat ekstrak jambu biji merah dengan cara jambu biji merah dipilih, dikupas dari kulitnya kemudian ditimbang 100 gram, lalu ditambah air 100 $\pm 0,05 \mathrm{ml}$ selanjutnya dihaluskan dengan blender, setelah itu ekstrak disaring untuk dipisahkan ampas (biji) dengan filtratnya. Tahapan selanjutnya membuat agensia curing terdiri dari $\mathrm{NaCl}$ $4 \%$, gula pasir $1 \%$, NaNO3 $0,1 \%$ dan NaNO2 0,05\%, dan ekstrak jambu biji merah merah yang bervariasi yaitu konsentrasi $0 \%$, $1 \%, 2 \%, 3 \%, 4 \%$ dan $5 \%$, lalu agensia curing tersebut dilarutkan air $150 \mathrm{ml}$. Tahapan selanjutnya memilih daging sapi bagian brisket, kemudian dibersihkan dari jaringanjaringan yang tidak dikehendaki, dipotong dadu, dicuci bersih, dan ditiriskan kurang lebih 1 menit. Daging yang didapatkan kemudian direndam dalam larutan curing dan disimpan pada suhu dingin $\left(0-4^{\circ} \mathrm{C}\right)$ selama 0 , 2, 4, dan 6 hari, dan perbandingan larutan curing dengan daging adalah $1: 1 \mathrm{~b} / \mathrm{v}$ (1 bagian daging ( \pm 100 gram): 1 bagian larutan curing).

\section{Rancangan percobaan}

Rancangan percobaan yang digunakan dalam penelitian ini adalah Rancangan Acak Lengkap dengan variasi konsentrasi ekstrak jambu biji merah $(0 \%, 1 \%, 2 \%, 3 \%, 4 \%$, dan $5 \%$ ) dan diamati pada lama perendaman 0,2 , 4, dan 6 hari. Analisis dilakukan dengan dua kali ulangan sampel dan dua kali ulangan analisis. Data yang didapatkan kemudian dianalisis dengan ANOVA untuk mengetahui beda nyata antar perlakuan pada tingkat $\alpha=$ $5 \%$, Jika ada yang beda nyata dilanjutkan dengan uji DMRT (Duncan Multiple Range Test) untuk mengetahui beda nyata antar perlakuan. Daging yang diberikan perlakuan curing dengan ekstrak jambu biji merah disimpan pada suhu rendah $\left(0-4^{\circ} \mathrm{C}\right)$ dengan kondisi tertutup wadah gelas kaca, kemudian dilakukan analisis kadar air (Sudarmadji, 2004), derajat keasaman (pH) (Suradi, 2006), WHC (water holding capacity) (Rini, 2019), tekstur (Younis, 2015), warna (Jading, 2018), kadar vitamin C (Sudarmadji, 2004), dan kadar residu nitrit (Romsiah, 2017) pada hari ke-0, 2, 4 dan 6.

\section{Pengujian sampel}

\section{Kadar air}

Daging dihancurkan dengan mortar sebanyak 1-2 gram, lalu dimasukkan kedalam botol timbang yang telah dikeringkan dalam oven pada suhu $105{ }^{\circ} \mathrm{C}$ selama 1 jam dan telah diketahui beratnya. Sampel dimasukkan kedalam botol timbang lalu ditimbang, selanjutnya dikeringkan didalam oven selama 6 jam dengan suhu 100$105{ }^{\circ} \mathrm{C}$, dan didinginkan dalam eksikator 15 menit dan ditimbang. Dilakukan pengovenan lagi selama 1 jam suhu $105{ }^{\circ} \mathrm{C}$. Proses pendinginan dalam eksikator dan ditimbang. Proses pengeringan diulang sampai diperoleh berat konstan (selisih penimbangan berturutturut 0,2 mg (Sudarmadji, 2004).

\section{2. $\mathbf{p H}$}

Daging dihancurkan sebanyak 10 gram, lalu dilarutkan dalam aquadest dengan perbandingan aquadest : daging sama dengan 5 : 1. Kemudian campuran daging dan aquadest ini ditera $\mathrm{pH}$ nya menggunakan $\mathrm{pH}$ meter (Suradi, 2006). 


\section{WHC (Water Holding Capacity)}

Daging dihaluskan dan ditimbang sebanyak 2 gram, dimasukkan ke dalam tabung sentrifus dan ditambah dengan $4 \mathrm{~mL}$ $\mathrm{NaCl} 0,6 \mathrm{M}$, kemudian ditutup dengan kapas+aluminium foil. Sampel dihomogenkan menggunakan vortex selama 30 detik. Sampel disimpan pada refrigenerator pada suhu $0-4{ }^{\circ} \mathrm{C}$ selama 30 menit. Tabung disentrifus dengan kecepatan 3000 rpm selama 30 menit (Rini, 2019).

\section{Tekstur}

Menggunakan software TexturePro CT V1.4 Build 17, sampel ditekan sebanyak 2 kali setiap sampel dilakukan uji 2 kali ulangan. Sampel diletakan di dalam wadah cup stainless stel dan diletakkan di papan spindel. Spindel yang digunakan adalah TA14 (Younis, 2015).

\section{Warna}

Daging diletakkan pada alas yang sudah disiapkan, alas berukuran lebar untuk memudahkan pembacaan sensor dengan color meter. Didapatkan hasil dengan pembacaan nilai $L^{*}$. $a^{*}$ dan $b^{*}$ pada alat color meter (Jading, 2018).

\section{Kadar asam askorbat (Vitamin C)}

Sebanyak 10 gram daging dilarutkan dengan aquadest dalam labu takar $100 \mathrm{ml}$ (Produk padat harus dihaluskan terlebih dahulu). Diambil sebanyak $10 \mathrm{ml}$ larutan sampel, ditambahkan indikator amilum $1 \mathrm{ml}$. Titik akhir titrasi ditandai dengan adanya perubahan warna menjadi biru setelah ditambahkan larutan iodine $0,01 \quad \mathrm{~N}$ (Sudarmadji, 2004).

\section{Residu nitrit}

Pertama pembuatan larutan pereaksi, lalu menentukan panjang gelombang maksimum dan operating time. Setelah semua diketahui lalu pembuatan larutan standar nitrit dan Penentuan Batas Deteksi (LOD) dan Batas Kuantitas (LOQ). Terakhir adalah pembuatan kurva standar yang dilanjutkan dengan analisis residu nitrit pada daging sapi dengan perlakuan curing (Romsiah, 2017).

\section{HASIL DAN PEMBAHASAN}

Penggunaan asam askorbat pada proses curing sangat diperlukan karena asam askorbat dapat menjadi suatu senyawa yang dapat menurunkan jumlah residu nitrit didalam proses curing. Pada penelitian ini, asam askorbat yang digunakan bersumber dari esktrak buah jambu biji merah. Kandungan asam askorbat jambu biji merah yang digunakan pada penelitian ini adalah 90,2 mg/100 gram bahan. Menurut Kementrian Kesehatan RI (2017), kandungan asam askorbat jambu biji merah $87 \mathrm{mg} / 100$ gram bahan, sedangkan menurut Batubara (2017), kandungan asam askorbat jambu biji merah antara rentang 68,376-136,75 mg/100 gram bahan. Nilai yang berbeda pada kandungan asam askorbat jambu biji merah menurut USDA (2001), kandungan asam askorbat jambu biji merah adalah 287 $\mathrm{mg} / 100$ gram bahan. Menurut Batubara (2017), perbedaan kandungan asam askorbat pada suatu bahan dapat disebabkan karena lama penyimpanan dan suhu saat penyimpanan.

Tabel 1 Nilai pH daging sapi dengan perlakuan curing menggunakan ekstrak jambu biji merah

\begin{tabular}{|c|c|c|c|c|}
\hline \multirow{2}{*}{$\begin{array}{l}\text { Konsentrasi ekstrak } \\
\text { jambu biji }(\mathrm{J})\end{array}$} & \multicolumn{4}{|c|}{ Kadar pH Pengamatan Hari Ke - } \\
\hline & 0 & 2 & 4 & 6 \\
\hline $\mathrm{J} 1: 0 \%$ & $5,95^{\text {eD }}$ & $5,86^{\mathrm{dC}}$ & $5,75^{\mathrm{fB}}$ & $5,62^{\mathrm{fA}}$ \\
\hline $\mathrm{J} 2: 1 \%$ & $5,91^{\mathrm{dD}}$ & $5,77^{\mathrm{c} \mathrm{C}}$ & $5,71^{\text {e } \mathrm{B}}$ & $5,58^{\text {e } \mathrm{A}}$ \\
\hline $\mathrm{J} 3: 2 \%$ & $5,90^{\mathrm{d} D}$ & $5,74^{\mathrm{c} \mathrm{C}}$ & $5,67^{\mathrm{d} B}$ & $5,53^{\mathrm{dA}}$ \\
\hline $\mathrm{J} 4: 3 \%$ & $5,85^{\mathrm{cD}}$ & $5,63^{b C}$ & $5,54^{\text {c B }}$ & $5,49^{\mathrm{c} \mathrm{A}}$ \\
\hline $\mathrm{J} 5: 4 \%$ & $5,73^{\text {b D }}$ & $5,60^{b C}$ & $5.50^{\text {b B }}$ & $5,46^{\mathrm{b} \mathrm{A}}$ \\
\hline J6 : $5 \%$ & $5,64^{\text {a C }}$ & $5,50^{\text {a } \mathrm{B}}$ & $5,45^{\text {a } \mathrm{AB}}$ & $5,42^{\text {a A }}$ \\
\hline
\end{tabular}

Keterangan:

Huruf kecil menunjukkan analisis statistika faktor beda konsentrasi, angka yang diikuti huruf sama menunjukkan tidak berbeda nyata dengan uji DMRT 5\% (berlaku pada kolom yang sama). Huruf kapital menunjukkan analisis statistika faktor lama perendaman, angka yang diikuti huruf sama menunjukkan tidak berbeda nyata dengan uji DMRT 5\% (berlaku pada baris yang sama). 


\section{Derajat Keasaman (pH)}

Pengujian $\mathrm{pH}$ pada daging sangat penting karena dapat mengetahui kualitasnya seperti daya ikat air dan tekstur (Soeparno, 2015). Nilai $\mathrm{pH}$ daging sapi (brisket) adalah 5,96. Tabel 1 menunjukkan bahwa lama perendaman dan banyaknya penambahan ekstrak jambu biji merah berpengaruh signifikan terhadap nilai $\mathrm{pH}$ pada daging $(p<0,05)$. Semakin lama perendaman dan semakin banyaknya ekstrak jambu biji merah yang ditambahkan maka nilai $\mathrm{pH}$ daging secara signifikan semakin kecil $(\mathrm{p}<0,05)$.

Perubahan nilai dari $\mathrm{pH}$ 5,95 menjadi $\mathrm{pH}$ akhir daging sapi dengan perlakuan curing 5,42 merupakan perubahan yang disebabkan oleh faktor konsentrasi ekstrak buah jambu biji merah dan lama perendaman. Penurunan $\mathrm{pH}$ daging diakibatkan kondisi asam yang diberikan oleh ekstrak jambu biji merah yang ditambahkan pada larutan curing, karena laju glikolisis dan pemecahan ATP terjadi pada kisaran $\mathrm{pH} 5,4-5,8$ (Soeparno, 2015). Menurut Islam (2009), lama waktu penyimpanan dan kondisi curing basah mempengaruhi penurunan $\mathrm{pH}$ daging karena bahan agensia curing belum bekerja maksimal. Menurut Pursudarsono (2015), $\mathrm{NaCl}$ yang ditambahkan pada daging akan terurai menjadi ion $\mathrm{Na}^{+}$yang akan dimanfaatkan oleh bakteri asam laktat untuk bertumbuh. Ion $\mathrm{Cl}^{-}$akan mengikat air bebas pada daging dan menciptakan suasana asam sedangkan gula yang ditambahkan sebagai salah satu bahan curing menurut Soeparno (2015) adalah salah satu faktor pendukung terbentuknya asam laktat dimana menciptakan $\mathrm{pH}$ yang rendah dan dapat menyebabkan konsentrasi $\mathrm{NaCl}$ semakin tinggi. Menurut Soeparno (2015), garam dan gula dapat menyebabkan penurunan aktivitas air dan juga dapat menstabilkan tekanan osmotik yang mengakibatkan $\mathrm{pH}$ daging turun.

Pola penurunan tersebut terjadi pada semua perlakuan konsentrasi penambahan asam askorbat. Penambahan asam askorbat dapat menurunkan $\mathrm{pH}$ daging dan dapat memperbaiki kualitas daging sapi (Soepano, 2015). Penambahan asam-asam organik seperti asam askorbat dapat menghambat terjadinya oksidasi dan dapat mengubah kondisi suatu produk menjadi semakin asam karena terjadi penurunan $\mathrm{pH}$ pada produk (Kosim, 2015).

Menurut Buckle (1985), $\mathrm{pH}$ rendah yang terjadi saat proses curing dibutuhkan untuk meningkatkan penyerapan bahan curing melalui struktur urat yang terbuka, mengendalikan pertumbuhan bakteri baik di dalam maupun di luar jaringan daging, dan mendapat warna merah yang diinginkan. Derajat keasaman $(\mathrm{pH})$ pada daging juga dapat mempengaruhi whe (water holding capacity) dan kadar air pada daging. Menurut Forrest (1975), laju penurunan $\mathrm{pH}$ pada daging akan mengakibatkan warna daging semakin pucat, daya ikat cairan akan semakin turun, dan permukaan daging akan basah karena semakin meningkatnya drip.

\section{Kadar Air dan WHC (Water Holding Capacity)}

Pada penelitian ini, kadar air daging sebelum diberikan perlakuan adalah 79,97\% . Hasil analisis kadar air daging pada berbagai perlakuan curing disajikan pada Tabel 2.

Tabel 2 menunjukkan bahwa lama perendaman dan banyak penambahan ekstrak jambu biji merah berpengauh signifikan terhadap nilai kadar air pada daging $(p<0,05)$. Semakin lama waktu perendaman dan semakin banyak penambahan ekstrak jambu biji merah mengakibatkan mengecilnya kadar air pada daging. Semakin lama waktu perendaman mengakibatkan mengecilnya kadar air pada daging. Menurut Sarassati (2015), penurunan kadar air pada daging sapi disebabkan oleh keluarnya drip dari daging, dengan semakin banyak drip yang keluar akan menunjukkan daya ikat air pada daging menurun. Proses keluarnya drip terjadi selama penyimpanan dingin yang disebabkan oleh interaksi dari protein daging dan pengkerutan otot yang dapat mengakibatkan kandungan air akan menurun.

Besarnya nilai $\mathrm{pH}$ pada daging juga dapat menentukan daya ikat air pada daging. Nilai WHC pada daging sebelum dilakukan perlakuan curing adalah 70,36\%. Hasil analisis WHC daging ditunjukkan pada Tabel 3. Berdasarkan Tabel 3, lama waktu perendaman dan penambahan ekstrak jambu biji merah pada proses curing mempengaruhi 
nilai water holding capacity pada daging. Semakin lama waktu perendaman yang dilakukan menyebabkan nilai WHC semakin kecil. Hasil analisis statistika yang dilakukan menggunakan ANOVA menunjukkan adanya pengaruh nyata lama perendaman dengan penambahan esktrak jambu biji merah terhadap nilai WHC pada daging.

Penurunan $\mathrm{pH}$ pada daging akan menurunkan daya ikat air. Air akan meninggalkan serabut otot dan meningkatkan aktomiosin (proses pemendekan miofilamen yang menyebabkan otot mengerut) yang dapat memeras cairan yang telah terdisosiasi dari protein keluar (Soeparno, 2015). Menurut Lawrie (2003), penambahan garam dan gula pada proses curing dapat mengeluarkan air dari dalam daging menuju larutan curing yang disebabkan adanya peningkatan tekanan osmosis dalam daging.
Nilai pH yang rendah dapat menyebabkan denaturasi protein sarkoplasma dan menyebabkan koagulasi protein pada miofibrilar. Kondisi ini akan mempengaruhi interaksi antara pemukaan protein dengan cairan yang dapat mengurangi kekuatan dalam menahan air. Rendahnya nilai $\mathrm{pH}$ juga disebabkan oleh akumulasi asam laktat yang dapat merusak protein miofibrilar dan menjadikan protein memiliki penurunan kemampuan dalam mengikat air (Rini, 2015). Perubahan daya ikat air pada daging juga diakibatkan dari perubahan ion-ion yang dapat diikat protein (Suradi, 2006). Adanya penambahan garam dan gula sebagai agensia curing dapat menyebabkan peningkatan pengikatan ion dan mempengaruhi tekanan osmotik. Tekanan osmotik yang berubah dapat menurunkan daya ikat air pada daging.

Tabel 2 Nilai kadar air (\%) daging sapi dengan perlakuan curing menggunakan ekstrak jambu biji merah

\begin{tabular}{|c|c|c|c|c|}
\hline \multirow{2}{*}{$\begin{array}{c}\text { Konsentrasi ekstrak } \\
\text { jambu biji }(\mathrm{J})\end{array}$} & \multicolumn{4}{|c|}{ Kadar Air (\%) Pengamatan Hari Ke - } \\
\hline & 0 & 2 & 4 & 6 \\
\hline $1: 0 \%$ & $79,91^{\mathrm{fB}}$ & $79,75^{\text {e B }}$ & $78,49^{\mathrm{d} A}$ & $77,83^{\mathrm{d} A}$ \\
\hline $\mathrm{J} 2: 1 \%$ & $79,80^{\text {e } D}$ & 79,42 e C & $77,73^{\mathrm{c} \mathrm{B}}$ & $76,85^{\mathrm{c} \mathrm{A}}$ \\
\hline $\mathrm{J} 3: 2 \%$ & $79,29^{\mathrm{d} D}$ & $78,82^{\mathrm{dC}}$ & $77,40^{\mathrm{c} \mathrm{B}}$ & 76,50 bc A \\
\hline $\mathrm{J} 4: 3 \%$ & $78,78^{\mathrm{cD}}$ & $78,22^{\mathrm{c} \mathrm{C}}$ & 76,83 b B & 75,83 ab A \\
\hline $\mathrm{J} 5: 4 \%$ & $77,63^{\text {b C }}$ & 77,39 b C & $76,46^{\text {b B }}$ & $75,56^{\text {a A }}$ \\
\hline $\mathrm{J} 6: 5 \%$ & $77,16^{\text {a B }}$ & $76,80^{\text {a } \mathrm{B}}$ & $75,63^{\text {a A }}$ & 75,34 a A \\
\hline
\end{tabular}

Keterangan:

Huruf kecil menunjukkan analisis statistika faktor beda konsentrasi, angka yang diikuti huruf sama menunjukkan tidak berbeda nyata dengan uji DMRT 5\% (berlaku pada kolom yang sama). Huruf kapital menunjukkan analisis statistika faktor lama perendaman, angka yang diikuti huruf sama menunjukkan tidak berbeda nyata dengan uji DMRT 5\% (berlaku pada baris yang sama).

Tabel 3 Nilai WHC (\%) daging sapi dengan perlakuan curing menggunakan ekstrak jambu biji merah

\begin{tabular}{|c|c|c|c|c|}
\hline \multirow{2}{*}{$\begin{array}{l}\text { Konsentrasi ekstrak } \\
\text { jambu biji (J) }\end{array}$} & \multicolumn{4}{|c|}{ WHC (\%) Pengamatan Hari Ke - } \\
\hline & 0 & 2 & 4 & 6 \\
\hline $\mathrm{J} 1: 0 \%$ & $70,36^{\mathrm{fD}}$ & $67,93^{\mathrm{eC}}$ & $65,27^{\mathrm{fB}}$ & $63,86^{\text {fA }}$ \\
\hline $\mathrm{J} 2: 1 \%$ & 70,03 e D & $67,58^{\mathrm{d} C}$ & $64,85^{\text {e B }}$ & 63,58 e A \\
\hline $\mathrm{J} 3: 2 \%$ & $69,69^{d D}$ & $66,94^{\mathrm{cC}}$ & $64,41 \mathrm{~d} \mathrm{~B}$ & $62,71^{\mathrm{d} A}$ \\
\hline $\mathrm{J} 4: 3 \%$ & $69,26^{\mathrm{cD}}$ & $65,88^{b C}$ & $63,99^{\text {c B }}$ & $61,71^{\mathrm{c} \mathrm{A}}$ \\
\hline $\mathrm{J} 5: 4 \%$ & $68,85^{b} \mathrm{D}$ & $65,70^{b C}$ & $63,03^{\mathrm{b} \mathrm{B}}$ & $61,01^{\mathrm{b} \mathrm{A}}$ \\
\hline $\mathrm{J} 6: 5 \%$ & $67,85^{\text {a } D}$ & $64,22^{\text {a C }}$ & $62,61^{\text {a B }}$ & $60,05^{\text {a A }}$ \\
\hline
\end{tabular}

Keterangan:

Huruf kecil menunjukkan analisis statistika faktor beda konsentrasi, angka yang diikuti huruf sama menunjukkan tidak berbeda nyata dengan uji DMRT 5\% (berlaku pada kolom yang sama). Huruf kapital menunjukkan analisis statistika faktor lama perendaman, angka yang diikuti huruf sama menunjukkan tidak berbeda nyata dengan uji DMRT 5\% (berlaku pada baris yang sama). 
Menurut Samodra (2010), asam askorbat merupakan salah satu senyawa antioksidan yang mampu menghambat kerusakan protein. Kemampuan asam askorbat dalam menahan laju penurunan daya ikat air masih kurang dan membutuhkan waktu yang cukup lama dalam penetrasi ke dalam daging. Menurut Jayathilakan (2007), asam askorbat juga mampu berperan menjadi reduktor. Pendapat yang sama juga diungkapkan oleh Soeparno (2015) bahwa asam askorbat mampu mendonorkan elektron yang dapat meningkatkan kontraksi aktomiosin dan dapat menurunkan daya ikat air pada daging. Menururt Zulfahmi (2010), kondisi pH lingkungan yang menurun juga dapat memicu menurunnya nilai daya ikat air pada daging, hal itu dibuktikan pada Tabel 2 mengenai kadar air daging yang menurun dari nilai awal 79,91 menjadi hasil akhir senilai 75,34, dan Tabel 3 mengenai daya ikat air dimana mengalami penurunan dari nilai awal sebesar 70,36 menjadi hasil akhir senilai 60,05 .
Tekstur (Hardness, Springiness, dan Cohesiveness)

Menurut Martinez (2004), tiga parameter yang dapat digunakan dalam menentukan tekstur produk daging dan olahan daging adalah nilai dari hardness, springiness, dan cohesiveness. Pengukuran Texture Profile Analysis (TPA) bertujuan untuk memberikan informasi terkait sampel pada saat masuk ke rongga mulut untuk dikunyah dan mencapai batas hingga dapat ditelan (Chorbadzhiev, 2017). Berdasarkan Tabel 4, lama waktu perendaman dan banyaknya penambahan ekstrak jambu biji merah memiliki pengaruh terhadap perubahan nilai hardness daging. Hasil pengujian menunjukkan bahwa semakin lama waktu perendaman dan semakin banyak penambahan ekstrak jambu biji merah maka nilai hardness semakin besar. Hasil pengujian springiness dapat dilihat pada Tabel 5. Penambahan ekstrak jambu biji merah sebagai sumber asam askorbat dan semakin lama perendaman akan membuat nilai cohesiveness menjadi lebih besar yang dapat dilihat pada Tabel 6.

Tabel 4 Nilai hardness (gram) daging sapi dengan perlakuan curing menggunakan ekstrak jambu biji merah

\begin{tabular}{|c|c|c|c|c|}
\hline \multirow{2}{*}{$\begin{array}{l}\text { Konsentrasi ekstrak } \\
\text { jambu biji (J) }\end{array}$} & \multicolumn{4}{|c|}{ Hardness (gram) Pengamatan Hari Ke - } \\
\hline & 0 & 2 & 4 & 6 \\
\hline $\mathrm{J} 1: 0 \%$ & $77,50^{\text {a } \mathrm{A}}$ & $83,50^{\text {a B }}$ & $85,75^{\text {a C }}$ & $89,75^{\text {a D }}$ \\
\hline $\mathrm{J} 2: 1 \%$ & $80,75^{\text {b A }}$ & 84,50 ab B & $86,75^{a b C}$ & 90,50 a D \\
\hline $\mathrm{J} 3: 2 \%$ & $82,00^{\text {b A }}$ & 85,25 b B & $87,00^{\mathrm{bC}}$ & $91,00^{\text {ab D }}$ \\
\hline $\mathrm{J} 4: 3 \%$ & 82,50 b A & $86,50^{\mathrm{c} \mathrm{B}}$ & 87,50 bc B & 91,50 ab C \\
\hline $\mathrm{J} 5: 4 \%$ & $85,50^{\mathrm{c} \mathrm{A}}$ & $87,25^{\mathrm{cd} \mathrm{B}}$ & $88,50^{\mathrm{cd} \mathrm{B}}$ & $92,50 \mathrm{bcC}$ \\
\hline $\mathrm{J} 6: 5 \%$ & $86,00^{\mathrm{c} \mathrm{A}}$ & $87,75^{\mathrm{d} B}$ & $89,25^{\mathrm{d} C}$ & $93,75^{\mathrm{cD}}$ \\
\hline
\end{tabular}

Keterangan:

Huruf kecil menunjukkan analisis statistika faktor beda konsentrasi, angka yang diikuti huruf sama menunjukkan tidak berbeda nyata dengan uji DMRT 5\% (berlaku pada kolom yang sama). Huruf kapital menunjukkan analisis statistika faktor lama perendaman, angka yang diikuti huruf sama menunjukkan tidak berbeda nyata dengan uji DMRT 5\% (berlaku pada baris yang sama). 
Tabel 5 Nilai springiness (milimeter) daging sapi dengan perlakuan curing menggunakan ekstrak jambu biji merah

\begin{tabular}{|c|c|c|c|c|}
\hline \multirow{2}{*}{$\begin{array}{c}\text { Konsentrasi ekstrak } \\
\text { jambu biji }(\mathrm{J})\end{array}$} & \multicolumn{4}{|c|}{ Springiness (milimeter) Pengamatan Hari Ke - } \\
\hline & 0 & 2 & 4 & 6 \\
\hline $\mathrm{J} 1: 0 \%$ & $3,14^{\text {a A }}$ & $4,15^{\text {a } \mathrm{A}}$ & $5,87^{\text {a } C}$ & $6,92^{\text {a D }}$ \\
\hline $\mathrm{J} 2: 1 \%$ & $3,58^{\mathrm{bA}}$ & $5,44^{\mathrm{b} \mathrm{A}}$ & $6,70^{\mathrm{bc}}$ & $7,64^{\mathrm{bD}}$ \\
\hline $\mathrm{J} 3: 2 \%$ & $4,43^{\mathrm{cA}}$ & $6,32^{\mathrm{cA}}$ & 6,81 bc C & $7,66^{\mathrm{bD}}$ \\
\hline $\mathrm{J} 4: 3 \%$ & $4,67^{\mathrm{d} A}$ & $6,48^{\mathrm{dA}}$ & $6,91^{\mathrm{cC}}$ & $8,52^{\mathrm{cD}}$ \\
\hline $\mathrm{J} 5: 4 \%$ & $5,42^{\mathrm{eA}}$ & $7,46^{\mathrm{e} A}$ & $7,75^{\mathrm{d} C}$ & $8,76^{\mathrm{dD}}$ \\
\hline $\mathrm{J} 6: 5 \%$ & $5,43^{\text {e A }}$ & $7,98^{\mathrm{fA}}$ & $8,48^{\text {e } \mathrm{C}}$ & $9,14^{\text {e D }}$ \\
\hline
\end{tabular}

Keterangan:

Huruf kecil menunjukkan analisis statistika faktor beda konsentrasi, angka yang diikuti huruf sama menunjukkan tidak berbeda nyata dengan uji DMRT 5\% (berlaku pada kolom yang sama). Huruf kapital menunjukkan analisis statistika faktor lama perendaman, angka yang diikuti huruf sama menunjukkan tidak berbeda nyata dengan uji DMRT 5\% (berlaku pada baris yang sama).

Tabel 6 Nilai cohesiveness daging sapi dengan perlakuan curing menggunakan ekstrak jambu biji merah

\begin{tabular}{|c|c|c|c|c|}
\hline \multirow{2}{*}{$\begin{array}{l}\text { Konsentrasi ekstrak } \\
\text { jambu biji }(\mathrm{J})\end{array}$} & \multicolumn{4}{|c|}{ Cohesiveness Pengamatan Hari Ke - } \\
\hline & 0 & 2 & 4 & 6 \\
\hline $\mathrm{J} 1: 0 \%$ & $0,36^{\mathrm{aA}}$ & $0,38^{\text {a A }}$ & $0,46^{\mathrm{aB}}$ & $0,48^{\text {a B }}$ \\
\hline $\mathrm{J} 2: 1 \%$ & 0,37 a A & $0,41^{\text {a A }}$ & 0,47 a в & $0,52^{\text {b B }}$ \\
\hline $\mathrm{J} 3: 2 \%$ & $0,51^{\mathrm{b} \mathrm{A}}$ & $0,51 \mathrm{~b} \mathrm{~A}$ & $0,56^{\mathrm{bA}}$ & $0,57^{\mathrm{c} \mathrm{A}}$ \\
\hline $\mathrm{J} 4: 3 \%$ & $0,55^{\mathrm{b} \mathrm{A}}$ & $0,56 \mathrm{bc} \mathrm{A}$ & $0,60^{\mathrm{cB}}$ & $0,63^{\mathrm{dB}}$ \\
\hline $\mathrm{J} 5: 4 \%$ & $0,62^{\mathrm{cA}}$ & $0,63^{\mathrm{c} \mathrm{A}}$ & $0,67^{\mathrm{dA}}$ & 0,68 e A \\
\hline $\mathrm{J} 6: 5 \%$ & $0,71^{\mathrm{dA}}$ & $0,72^{\mathrm{d} A}$ & $0,74^{\mathrm{e}} \mathrm{B}$ & $0,80^{\mathrm{fC}}$ \\
\hline
\end{tabular}

Keterangan:

Huruf kecil menunjukkan analisis statistika faktor beda konsentrasi, angka yang diikuti huruf sama menunjukkan tidak berbeda nyata dengan uji DMRT 5\% (berlaku pada kolom yang sama). Huruf kapital menunjukkan analisis statistika faktor lama perendaman, angka yang diikuti huruf sama menunjukkan tidak berbeda nyata dengan uji DMRT 5\% (berlaku pada baris yang sama).

Hardness merupakan tingkat kekerasan pada sampel yang dilakukan dengan penghancuran sampel menggunakan daya. Proses pengancuran dilakukan hingga sampel hancur (Szczesniak, 2002). Daging sapi yang digunakan sebagai sampel sebelum dilakukan perlakuan curing memiliki nilai hardness 77,25 gram. Nilai hardness yang semakin tinggi menunjukkan semakin keras, karena gaya untuk menekan bahan yang dibutuhkan semakin besar pula. Hubungan antara kadar air dan hardness adalah berbanding terbalik. Saat daging kehilangan air di dalam otot, maka nilai hardness daging akan meningkat (Serra, 2005). Menurut Soeparno (2015), asam askorbat yang merupakan salah satu asam organik dapat mendonorkan elektron ke daging. Pengaruh penambahan asam askorbat adalah meningkatkan aktomiosin dan dapat memberikan efek pemendekan serabut otot. Kadar garam dan gula yang ada pada larutan curing akan mengubah tekanan osmotik pada

daging dan akan mengeluarkan air dari daging (Lawrie, 2003).Springiness merupakan parameter yang dinilai dari sampel melalui kemampuan sampel untuk kembali ke kondisi semula setelah gaya dihilangkan. Istilah lain dari pengujuan ini adalah pengukuran daya elastisitas suatu sampel (Wijayanti, 2015). Nilai springiness daging sebelum diproses yaitu 3,13 milimeter. Nilai springiness yang semakin naik menunjukkan mudahnya bahan kembali ke kondisi semula. Springiness merupakan parameter yang dinilai dari sampel melalui kemampuan sampel untuk kembali ke kondisi semula setelah gaya dihilangkan. Istilah lain dari pengujuan ini adalah pengukuran daya elastisitas suatu sampel (Wijayanti, 2015). Nilai springiness yang semakin naik menunjukkan mudahnya bahan kembali ke kondisi semula. Hasil nilai springiness daging semakin tinggi dari nilai 3,14 menjadi 9,14. Kekuatan aktivitas air 
menurun maka akan menaikkan springiness. Menurut Samodra (2010), asam askorbat salah satu antioksidan yang mampu menghambat kerusakan protein. Menurut Jayathilakan (2007), asam askorbat juga mampu berperan menjadi reduktor. Pendapat yang sama juga diungkapkan oleh Soeparno (2015) bahwa asam askorbat mampu mendonorkan elektron yang dapat meningkatkan kontraksi aktomiosin dan dapat menurunkan daya ikat air pada daging.

Cohesiveness merupakan suatu parameter yang pengujiannya dilakukan dengan cara melihat suatu sampel dari segi kekompakan materi jika ditekan dengan cara dimasukkan di antara gigi (Szczesniak, 2002). Kekompakan (kekuatan interaksi) dari sampel yang akan membentuk tekstur sampel dengan dua kriteria, kompak jika bernilai 1 dan kurang kompak apabila berada diantara nilai $0,0-1,0$ (Indarto dkk., 2007). Nilai cohesiveness yang semakin besar menunjukkan tidak mudahnya suatu bahan berubah bentuk jika mengalami tekanan. Menurut Soeparno (2015), garam dan gula dapat menyebabkan penurunan aktivitas air dan juga dapat menstabilkan tekanan osmotik yang mengakibatkan $\mathrm{pH}$ daging turun. Kondisi ini terjadi jika kekuatan aktivitas air menurun maka nilai cohesiveness meningkat. Menurut Indiarto (2012), naik turunnya nilai cohesiveness dapat dipengaruhi oleh faktor nilai parameter turunan yaitu nilai brittleness, chewiness dan gumminess (Indiarto, 2012).
Pengaruh coheviness juga dipengaruhi oleh komponen penyusun agensia curing yang lain. Menurut Wulan (2019), penambahan $\mathrm{NaCl}$ pada suatu sampel akan mempertebal dinding sel yang disebabkan oleh terbentuknya kalsium pekat yang menyebabkan tekstur sampel lebih kompak dan keras.

\section{Warna ( $\left.L^{*}, a^{*}, \operatorname{dan} b^{*}\right)$}

Warna menjadi salah satu parameter penting dalam penentuan mutu sebuah pangan karena berkaitan dengan penilaian sensoris fisik. Indikator pengujian warna yang digunakan meliputi parameter nilai $\mathrm{L}^{*}$, $a^{*}$, dan $b^{*}$. $L^{*}$ adalah adalah parameter Lightness (kecerahan) dengan nilai antara 0 (hitam) sampai 100 (putih), $\mathrm{a}^{*}$ adalah parameter warna merah dengan nilai positif dan warna hijau dengan nilai negatif, dan $b^{*}$ merupakan parameter warna kuning dengan nilai positif dan warna biru dengan nilai negatif (Jading, 2018). Tabel 7 menunjukkan adanya pengaruh antara lama perendaman dan penambahan ekstrak jambu biji merah dengan nilai warna $L^{*}$ daging sapi dengan perlakuan curing. Tabel 8 menunjukkan lama waktu perendaman dan penambahan asam askorbat memiliki pengaruh terhadap nilai uji warna $a^{*}$ daging. Tabel 9 menunjukkan adanya pengaruh lama waktu perendaman dan penambahan ekstrak jambu biji merah tehadap nilai warna $b^{*}$ daging.

Tabel 7 Nilai warna L* daging sapi dengan perlakuan curing menggunakan ekstrak jambu biji merah

\begin{tabular}{|c|c|c|c|c|}
\hline \multirow{2}{*}{$\begin{array}{l}\text { Konsentrasi ekstrak } \\
\text { jambu biji (J) }\end{array}$} & \multicolumn{4}{|c|}{ Warna L* Pengamatan Hari Ke - } \\
\hline & 0 & 2 & 4 & 6 \\
\hline $\mathrm{J} 1: 0 \%$ & $36,83^{\text {a } A}$ & $40,50^{\text {a B }}$ & $42,19^{\text {a C }}$ & $44,65^{\text {a D }}$ \\
\hline $\mathrm{J} 2: 1 \%$ & $38,75^{\text {b A }}$ & 41,00 ab B & $43,48^{b C}$ & $46,65^{\text {b D }}$ \\
\hline $\mathrm{J} 3: 2 \%$ & 39,51 b A & $41,57 \mathrm{bc} \mathrm{B}$ & $44,25^{\mathrm{cC}}$ & 47,38 bc D \\
\hline $\mathrm{J} 4: 3 \%$ & 39,96 bc A & $42,33^{\text {c B }}$ & $44,99 \mathrm{~d} \mathrm{C}$ & $47,80^{\text {bc D }}$ \\
\hline $\mathrm{J} 5: 4 \%$ & $40,94^{\mathrm{c} \mathrm{A}}$ & $43,43^{\mathrm{d} \mathrm{B}}$ & $45,57^{\mathrm{dC}}$ & $48,69^{\mathrm{cd} D}$ \\
\hline $\mathrm{J} 6: 5 \%$ & $42,86^{\mathrm{d} A}$ & 44,65 e $\mathrm{B}$ & $47,19^{\text {e } C}$ & $49,75^{\text {e D }}$ \\
\hline
\end{tabular}

Keterangan:

Huruf kecil menunjukkan analisis statistika faktor beda konsentrasi, angka yang diikuti huruf sama menunjukkan tidak berbeda nyata dengan uji DMRT 5\% (berlaku pada kolom yang sama). Huruf kapital menunjukkan analisis statistika faktor lama perendaman, angka yang diikuti huruf sama menunjukkan tidak berbeda nyata dengan uji DMRT 5\% (berlaku pada baris yang sama). 
Tabel 8 Nilai warna a* daging sapi dengan perlakuan curing menggunakan ekstrak jambu biji merah

\begin{tabular}{|c|c|c|c|c|}
\hline \multirow{2}{*}{$\begin{array}{c}\text { Konsentrasi ekstrak } \\
\text { jambu biji }(\mathrm{J})\end{array}$} & \multicolumn{4}{|c|}{ Warna a* Pengamatan Hari Ke - } \\
\hline & 0 & 2 & 4 & 6 \\
\hline $\mathrm{J} 1: 0 \%$ & $11,51^{\mathrm{a} \mathrm{A}}$ & $12,95^{\mathrm{a} B}$ & $14,85^{\mathrm{a} \mathrm{C}}$ & $15,72^{\text {a D }}$ \\
\hline $\mathrm{J} 2: 1 \%$ & 11,91 ab A & $13,11^{\text {a } \mathrm{B}}$ & $15,12^{\text {a } \mathrm{C}}$ & $16,39^{b D}$ \\
\hline $\mathrm{J} 3: 2 \%$ & $12,49^{\mathrm{b} \mathrm{A}}$ & $13,34^{\mathrm{b} \mathrm{B}}$ & $16,08^{\mathrm{b} C}$ & $16,78^{\mathrm{cD}}$ \\
\hline $\mathrm{J} 4: 3 \%$ & $13,46^{\mathrm{cA}}$ & $14,49^{\text {c } \mathrm{B}}$ & $16,32^{b c}$ & $17,46^{d \mathrm{D}}$ \\
\hline $\mathrm{J} 5: 4 \%$ & $14,70^{\mathrm{dA}}$ & $15,53^{\mathrm{d} \mathrm{B}}$ & $17,33^{\mathrm{c} \mathrm{C}}$ & $18,74^{\text {e D }}$ \\
\hline J6 : 5\% & $14,76^{\mathrm{d} \mathrm{A}}$ & $16,33^{\text {e } \mathrm{B}}$ & $17,71^{\mathrm{c} \mathrm{C}}$ & $19,38^{f D}$ \\
\hline
\end{tabular}

Keterangan:

Huruf kecil menunjukkan analisis statistika faktor beda konsentrasi, angka yang diikuti huruf sama menunjukkan tidak berbeda nyata dengan uji DMRT 5\% (berlaku pada kolom yang sama). Huruf kapital menunjukkan analisis statistika faktor lama perendaman, angka yang diikuti huruf sama menunjukkan tidak berbeda nyata dengan uji DMRT 5\% (berlaku pada baris yang sama).

Tabel 9 Nilai warna $b^{*}$ daging sapi dengan perlakuan curing menggunakan ekstrak jambu biji merah

\begin{tabular}{|c|c|c|c|c|}
\hline \multirow{2}{*}{$\begin{array}{l}\text { Konsentrasi ekstrak } \\
\text { jambu biji }(\mathrm{J})\end{array}$} & \multicolumn{4}{|c|}{ Warna $b^{*}$ Pengamatan hari ke } \\
\hline & 0 & 2 & 4 & 6 \\
\hline $\mathrm{J} 1: 0 \%$ & $9,45^{\mathrm{eC}}$ & $8,46^{\mathrm{e} B}$ & $7,99^{\mathrm{e} B}$ & $6,82^{\mathrm{dA}}$ \\
\hline $\mathrm{J} 2: 1 \%$ & $9,03^{\mathrm{d} \mathrm{C}}$ & $7,48^{\mathrm{d} \mathrm{B}}$ & 7,83 de $B$ & $6,59^{\mathrm{cd} A}$ \\
\hline $\mathrm{J} 3: 2 \%$ & $8,54^{\mathrm{c} \mathrm{C}}$ & $7,40^{\mathrm{cd} \mathrm{B}}$ & $7,57^{\mathrm{cd} \mathrm{B}}$ & $6,41^{\mathrm{c} \mathrm{A}}$ \\
\hline $\mathrm{J} 4: 3 \%$ & $7,67^{\mathrm{b} C}$ & $6,83 \mathrm{bc} \mathrm{B}$ & 7,07 bc B & $5,83^{\mathrm{b} \mathrm{A}}$ \\
\hline $\mathrm{J} 5: 4 \%$ & $7,36^{\text {ab C }}$ & $6,41^{\text {ab B }}$ & $6,47^{\text {b B }}$ & $5,56^{\text {b A }}$ \\
\hline $\mathrm{J} 6: 5 \%$ & $7,16^{\text {a D }}$ & $6,12^{\text {a } C}$ & 5,45 а в & $3,85^{\text {a A }}$ \\
\hline
\end{tabular}

Keterangan:

Huruf kecil menunjukkan analisis statistika faktor beda konsentrasi, angka yang diikuti huruf sama menunjukkan tidak berbeda nyata dengan uji DMRT 5\% (berlaku pada kolom yang sama). Huruf kapital menunjukkan analisis statistika faktor lama perendaman, angka yang diikuti huruf sama menunjukkan tidak berbeda nyata dengan uji DMRT 5\% (berlaku pada baris yang sama).

Warna $\mathrm{L}^{*}$ merupakan salah satu parameter kecerahan dari sampel yang menyatakan cahaya pantul dengan hasil warna kromatik hitam, abu-abu, dan putih (Rahmawati, 2012). Nilai warna $\left(\mathrm{L}^{*}\right)$ pada daging sebelum diproses curing adalah 43,02. Semakin lama waktu perendaman dan semakn banyak penambahan ekstrak jambu bijimerah menunjukkan nilai warna $L^{*}$ yang semakin besar. Warna $L^{*}$ merupakan salah satu parameter kecerahan dari sampel yang menyatakan cahaya pantul dengan hasil warna kromatik hitam, abu-abu, dan putih (Rahmawati, 2012). Besarnya nilai hasil pengujian warna $\mathrm{L}^{*}$ pada daging dipengaruhi oleh beberapa faktor, salah satunya yaitu kadar air yang memiliki hubungan berbanding terbalik dengan nilai $\mathrm{L}^{*}$ (Rahmawati, 2012). Daging segar yang tidak melalui proses nitrifikasi akan lebih dominan berwarna gelap sehingga nilai $L^{*}$ yang dihasilkan juga kecil (Costa, 2008). Gimeno (2000) mengungkapan bahwa kecerahan daging juga dipengatuhi oleh faktor pengikatan ion-ion yang diakibatkan adanya perendaman dengan garam. Reaksi tersebut yang menyebabkan adanya denaturasi protein.

Nilai warna $a^{*}$ dipengaruhi oleh lama waktu perendaman yang keduanya memiliki hubungan berbanding lurus, dimana semakin lama waktu perendaman maka nilai warna $\mathrm{a}^{*}$ juga semakin besar. Semua perlakukan dengan faktor lama perendaman yang semakin lama dan penambahan asam askorbat semakin banyak memberikan kenaikan yang signifikan. Parameter warna a* menunjukan kriteria warna merah jika bernilai positif dan menunjukkan wana hijau jika bernilai positif (Jading, 2018). Nilai Warna $a^{*}$ pada daging sebelum diberikan perlakuan curing adalah 15,45. Parameter warna a* menunjukan kriteria warna merah jika bernilai positif dan menunjukkan wana hijau jika bernilai positif (Jading, 2018). Menurut Samodra (2010), asam askorbat merupakan salah satu senyawa antioksidan yang mampu menghambat kerusakan protein. 
Kemampuan asam askorbat dalam menahan laju penurunan daya ikat air masih kurang dan membutuhkan waktu yang cukup lama dalam penetrasi ke dalam daging. Menurut Islam (2009), lama waktu penyimpanan dan kondisi curing basah mempengaruhi pada penurunan $\mathrm{pH}$ daging, karena bahan agensia curing belum bekerja maksimal.

Semakin lama waktu perendaman dan semakin banyak ekstrak jambu biji merah menyebabkan nilai warna $b^{*}$ semakin kecil. Nilai terbesar hasil analisis daging adalah 9,45 dan nilai terkecilnya adalah 3,85 . Warna $b^{*}$ merupakan salah satu parameter uji warna yang akan memberikan warna kuning apabila bernilai positif dan warna biru apabila bernilai negatif (Jading, 2018). Nilai $b^{*}$ dipengaruhi oleh oksimioglobin yang terjadi karena reaksi mioglobin dengan oksigen (Rahmawati, 2012). Nitrosomioglobin merupakan hasil reaksi antara nitrit dengan mioglobin, lalu dari reaksi tersebut dapat meyebabkan penurunan konsentrasi mioglobin dan oksimioglobin (Alvarez, 1999). Penurunan kandungan oksimioglobin dalam daging menyebabkan nilai $b^{*}$ menurun. Pembentukan warna $L^{*}$ dan warna $a^{*}$ akan menyebabkan rendahnya warna $b^{*}$ pada ham (Costa, 2008).

Faktor-faktor yang mempengaruhi perubahan warna daging selama proses penyimpanan daging, yaitu $\mathrm{pH}$, suhu, dan kelembaban (Costa, 2008). Menurut Esteban (2003), warna $\mathrm{L}^{*}$ pada daging dipengaruhi oleh presentasi dari metmioglobin dan oksimioglobin. Selain itu, faktor lain yang berpengaruh yaitu perpindahan air ke permukaan daging, $\mathrm{pH}$, struktur otot, bahan tambahan, spesies, kandungan lemak, dan daya ikat air. Costa (2008) dan Esteban (2003) menyatakan bahwa warna $L^{*}$ dan warna $a^{*}$ yang terbentuk nantinya dapat membuat warna $b^{*}$ lebih rendah pada daging. Menurut Lawrie (2003), penambahan nitrit pada proses curing bertujuan untuk menstabilkan warna pada daging. Asam askorbat bertindak sebagai zat pereduksi yang dapat mereduksi metmioglobin menjadi mioglobin yang kemudian bereaksi dengan nitrit oksida lalu menghasilkan nitrosomioglobin yang berwarna merah cerah (Soeparno, 2015). Reaksi antara nitrit dan asam askorbat ini akan membentuk warna merah cerah yang disebut nitrosomioglobin. Faktor lain yang berperan dalam pembentukan warna merah selain reaksi antara nitrit dengan asam askorbat adalah faktor kondisi seperti kondisi tertutup dan tidak terkena cahaya yang menjadikan tidak mengalami disklorasi (Soeparno, 2015).

Warna daging bergantung dari konsentrasi dan tipe molekul mioglobin, kondisi kimia, fisik, serta komponen lain dalam daging (Soeparno, 2015). Asam askorbat akan memberikan elektron pada nitrit sehingga terbentuk nitrit oksid. Reaksi pewarnaan pada curing dengan penambahan asam askorbat dapat terjadi secara lambat karena adanya zat pereduksi yang dapat mereduksi metmioglobin menjadi mioglobin dan kemudian bereaksi dengan nitrit oksid menghasilkan nitrit oksid mioglobin yang berwarna merah cerah (Borenstain, 1976). Daging sapi dengan perlakuan curing akan membuat nukleus hematin berbentuk utuh (normal) dan protein dalam masih dalam bentuk alami, namun akan merubah komposisi warna pada daging dan valensi $\mathrm{Fe}$ pada daging curing bervariasi (Lawrie, 2003).

\section{Analisis Asam Askorbat (Vitamin C)}

Lama waktu perendaman dan penambahan ekstrak jambu biji merah menyebabkan hasil pengujian asam askorbat pada daging semakin besar dan menyebabkan kandungan asam askorbat pada larutan curing semakin kecil. Kenaikan nilai asam askorbat pada pengujian daging dan penurunan nilai asam askorbat pada pengujian larutan curing dapat dilihat pada Tabel 10. Nilai asam askorbat pada jambu biji merah adalah 90,2 mg/100 gram dengan $\mathrm{pH} 4,2$. Asam askorbat yang terdapat pada larutan curing akan masuk ke dalam daging untuk memaksimalkan proses curing dan mengurangi kandungan nitrit yang telah masuk ke dalam serat-serat daging. Pengujian asam askorbat meliputi asam askorbat yang terdapat pada larutan curing sebagai sisa asam askorbat dan pengujian asam askorbat yang terdapat pada daging sebagai nilai asam askorbat yang mampu berpenetrasi ke dalam daging. 
Tabel 10 Nilai asam askorbat (mg/100 gram bahan) daging sapi dengan perlakuan curing menggunakan ekstrak jambu biji merah dan nilai asam askorbat (mg/100 gram, bahan) larutan curing

\begin{tabular}{|c|c|c|c|c|c|c|c|c|}
\hline \multirow{3}{*}{$\begin{array}{c}\text { Konsentrasi } \\
\text { ekstrak } \\
\text { jambu biji } \\
\text { (J) }\end{array}$} & \multicolumn{8}{|c|}{ Kandungan Asam Askorbat (mg/100 gram bahan) Pengamatan Hari Ke - } \\
\hline & \multicolumn{2}{|c|}{0} & \multicolumn{2}{|c|}{2} & \multicolumn{2}{|c|}{4} & \multicolumn{2}{|c|}{6} \\
\hline & Daging & Larutan & Daging & Larutan & Daging & Larutan & Daging & Larutan \\
\hline $\mathrm{J} 1: 0 \%$ & $0,00^{a-}$ & $0,00^{a-}$ & $0,00^{a-}$ & $0,00^{a-}$ & $0,00^{a-}$ & $0,00^{a-}$ & $0,00^{a-}$ & $0,00^{a-}$ \\
\hline $\mathrm{J} 2: 1 \%$ & $6,05^{\mathrm{b} \mathrm{A}}$ & $40,15^{\mathrm{d} D}$ & $11,00^{\text {b B }}$ & 35,20 e C & $14,30^{\mathrm{bC}}$ & $31,90^{\mathrm{d} B}$ & $18,70^{\mathrm{bD}}$ & 27,50 e $\mathrm{A}$ \\
\hline $\mathrm{J} 3: 2 \%$ & $7,15^{\mathrm{b} \mathrm{A}}$ & $39,60^{\mathrm{d} C}$ & $15,40^{\mathrm{c} \mathrm{B}}$ & $31,35^{\mathrm{d} B}$ & $17,05^{\mathrm{c} \mathrm{C}}$ & $29,70^{\mathrm{cd} \mathrm{B}}$ & $22,55^{\mathrm{cD}}$ & $24,20^{\mathrm{d} \mathrm{A}}$ \\
\hline $\mathrm{J} 4: 3 \%$ & $9,35^{\mathrm{cA}}$ & $37,95^{\mathrm{cd} \mathrm{C}}$ & $18,15^{\mathrm{d} \mathrm{B}}$ & $29,15^{\mathrm{cd} \mathrm{B}}$ & $20,35^{\mathrm{d} C}$ & $26,95^{\text {c B }}$ & $25,30^{\mathrm{d} D}$ & $22,00^{\mathrm{d} A}$ \\
\hline J5 : 4\% & $12,10^{\mathrm{d} A}$ & $35,75^{\mathrm{c} \mathrm{C}}$ & $21,45^{\text {e } \mathrm{B}}$ & 26,40 bc B & $24,75^{\text {e } \mathrm{C}}$ & $23,10^{\text {b B }}$ & $29,70^{\text {e D }}$ & $18,15^{\mathrm{c} \mathrm{A}}$ \\
\hline $\mathrm{J} 6: 5 \%$ & $18,15^{\text {e } \mathrm{A}}$ & $30,80^{\mathrm{b} D}$ & $23,65^{\mathrm{fB}}$ & $25,30^{\mathrm{bC}}$ & $28,60^{f C}$ & $20,35^{\text {b B }}$ & $36,85^{f D}$ & $12,10^{\mathrm{b} \mathrm{A}}$ \\
\hline
\end{tabular}

Keterangan:

Huruf kecil menunjukkan analisis statistika faktor beda konsentrasi, angka yang diikuti huruf sama menunjukkan tidak berbeda nyata dengan uji DMRT 5\% (berlaku pada kolom yang sama). Huruf kapital menunjukkan analisis statistika faktor lama perendaman, angka yang diikuti huruf sama menunjukkan tidak berbeda nyata dengan uji DMRT 5\% (berlaku pada baris yang sama), tanda "-” berarti tidak ada hasil analisis statistika karena angka yang sama 0 .

Ketika $\mathrm{pH}$ daging berada pada kisaran 5,5 - 6,0 dalam larutan air, sebagian nitrit dapat ditemukan dalam bentuk asam nitrit $\left(\mathrm{HNO}_{2}\right)$. Kondisi $\mathrm{pH}$ tersebut menyebabkan asam nitrit mengalami dekomposisi menjadi nitrit oksida (Soeparno, 2015). Nitrit juga dapat direduksi menjadi nitrit oksida melalui aktivitas reduksi alami dari jaringan otot postmortem. Akan tetapi, prosesnya berlangsung lambat dan memerlukan banyak substrat sebagai perantara dan enzim di dalam siklus TCA. Substrat dan enzim tersebut dapat memenuhi ekuivalen pereduksi (atom hidrogen dan elektron) sebagai NADH yaitu bentuk reduksi dari NAD+. Pada kondisi anaerobik, ekuivalen pereduksi ini dipergunakan untuk rantai transpor elektron mitokondria untuk mereduksi nitrit (Soeparno, 2015). Menurut Samodra (2010), asam askorbat merupakan salah satu senyawa antioksidan yang mampu menghambat kerusakan protein. Kemampuan asam askorbat dalam menahan laju penurunan daya ikat air masih kurang dan membutuhkan waktu yang cukup lama dalam penetrasi ke dalam daging. Menurut Islam (2009), lama waktu penyimpanan dan kondisi curing basah mempengaruhi pada penurunan $\mathrm{pH}$ daging, karena bahan agensia curing belum bekerja maksimal.

Menurut Soeparno (2015), asam askorbat merupakan agensia pereduksi atau sebagai reduktan yang memberikan elektronnya pada nitrit sehingga tujuan ditambahkan pada proses curing untuk mempercepat pembentukan nitrit menjadi nitrit oksida yang dapat menurunkan residu nitrit dalam daging selama proses curing. Selain itu, proses refrigasi juga menjadi salah satu faktor pendukung dalam menurunkan residu nitrit selama proses penyimpanan. Asam askorbat bertindak juga sebagai antioksidan ataupun pro-oksidan. Level yang tepat untuk pencegahan disklorasi otot tidak langsung dan tergantung faktor pendukung lainnya (Soeparno, 2015). Semakin cepat nitrit diubah menjadi nitrit oksida semakin kecil pula residu nitrit pada daging. Senyawa asam askorbat berperan sebagai zat pereduksi yang dapat mereduksi metmioglobin menjadi mioglobin kemudian bereaksi dengan nitrit oksida menghasilkan nitrosomioglobin yang berwarna merah cerah (Costa, 2008).

Pembentukan nitrit oksida dari nitrat dan nitrit dalam proses curing berjalan lambat. Tidak semua nitrit diubah menjadi nitrit oksida. Peran asam askorbat sangat penting di sini untuk mengendalikan proses curing guna mempercepat pembentukan nitrit oksida. Menurut Lawrie (2003), penambahan asam askorbat dapat mempercepat pembentukan nitrit oksida dari nitrit. Rreaksi ini dapat menurunkan kadar nitrit dalam daging, sehingga residu nitrit dalam daging juga rendah. 
Tabel 11 Nilai residu nitrit (ppm) daging sapi dengan perlakuan curing menggunakan ekstrak jambu biji merah

\begin{tabular}{|c|c|c|c|c|}
\hline \multirow{2}{*}{$\begin{array}{l}\text { Konsentrasi ekstrak } \\
\text { jambu biji }(\mathrm{J})\end{array}$} & \multicolumn{4}{|c|}{ Residu Nitrit (ppm) Pengamatan Hari Ke - } \\
\hline & 0 & 2 & 4 & 6 \\
\hline $\mathrm{J} 1: 0 \%$ & $10,62^{\mathrm{d} A}$ & $54,70^{\mathrm{fB}}$ & $57,77^{\mathrm{fD}}$ & $56,48^{\mathrm{fC}}$ \\
\hline $\mathrm{J} 2: 1 \%$ & $9,78^{\mathrm{c} \mathrm{A}}$ & 47,78 e C & $48,37^{\text {e } C}$ & $42,64^{\text {e B }}$ \\
\hline $\mathrm{J} 3: 2 \%$ & $9,41^{\mathrm{c} \mathrm{A}}$ & $39,78^{\mathrm{d} C}$ & $40,86^{\mathrm{d} D}$ & $38,86^{\mathrm{d} B}$ \\
\hline $\mathrm{J} 4: 3 \%$ & 8,74 b A & $31,50^{\mathrm{cC}}$ & $33,48^{c D}$ & $30,23^{\text {c B }}$ \\
\hline $\mathrm{J} 5: 4 \%$ & $8,50^{\mathrm{b} \mathrm{A}}$ & 26,12 b C & 27,39 b D & 24,18 b B \\
\hline $\mathrm{J} 6: 5 \%$ & $7,94^{\text {a A }}$ & $19,50^{\text {a C }}$ & 20,47 a D & 18,71 a B \\
\hline
\end{tabular}

Keterangan:

Huruf kecil menunjukkan analisis statistika faktor beda konsentrasi, angka yang diikuti huruf sama menunjukkan tidak berbeda nyata dengan uji DMRT 5\% (berlaku pada kolom yang sama). Huruf kapital menunjukkan analisis statistika faktor lama perendaman, angka yang diikuti huruf sama menunjukkan tidak berbeda nyata dengan uji DMRT 5\% (berlaku pada baris yang sama).

\section{Analisis Residu Nitrit}

Tabel 11 menunjukkan hasil analisis residu nitrit pada daging sapi dengan perlakuan curing. Pada penambahan ekstrak jambu biji merah dihasilkan bahwa nilai residu nitrit yang dihasilkan nilainya semakin menurun. Dilihat dari lama perendaman akan ada peningkatan dari hari 0 hingga hari 4 , hal itu karena asam askorbat belum masuk secara maksimal. Lama perendaman dari hari 4 menuju hari 6 akan mengalami penurunan karena asam askorbat sudah masuk dan terjadi reduksi metmiglobin. Hasil analisis menunjukkan pada semua perlakuan curing memberikan pengaruh yang signifikan. Hasil pengujian residu nitrit pada daging yang diberikan perlakuan curing memiliki nilai terbesar 57,77 ppm dan nilai terkecil 7,94 ppm.

Menurut Ermawati (2008), proses kenaikan residu nitrit lalu mengalami penurunan residu nitrit diakibatkan nitrit akan berpenetrasi masuk ke dalam struktur daging sehingga pada awal pengujian didapatkan nilai residu nitrit tinggi. Setelah asam askorbat juga masuk ke dalam daging, nilai residu nitrit mulai menurun karena penambahan asam askobat ke dalam larutan curing akan mempercepat reduksi metmioglobin dan mengonversi nitrit menjadi nitrit oksida. Daging sendiri dapat menurunkan nilai nitrit yang ada, namun dalam kurun waktu yang lama dan dengan penurunan residu yang kecil, maka dari itu membutuhkan asam askorbat untuk menurunkan residu nitrit lebih besar dan dengan waktu lebih cepat (Soeparno, 2015).
Nitrit oksida ini akan bereaksi dengan mioglobin membentuk nitrit oksida mioglobin yang berwarna merah cerah. Nitrit mengonversikan oksiomioglobin menjadi metmioglobin sedangkan asam askorbat sendiri menghasilkan campuran metmioglobin dan koleglobin (Soeparno, 2015).

Faktor lain yang menyebabkan penurunan nilai residu nitrit yaitu kondisi $\mathrm{pH}$ lingkungan selama proses curing berlangsung (Izumi, 1989). Menurut Toldrá (2010), Jika pH lebih tinggi dari 5,7 maka pembentukan nitrat akan sedikit dan pada $\mathrm{pH}$ lebih rendah dari 5,7 maka pembentukan nitrat akan bertambah. Nitrit yang masuk ke dalam daging berasal dari nitrit dan dari nitrat yang telah berubah menjadi nitrit. Hasil analisis residu nitrit pada daging menunjukkan adanya penurunan dengan besarnya ekstrak jambu biji merah yang digunakan. Secara umum, semua perlakuan menunjukkan bahwa pada perendaman hari ke-0 hingga hari ke-4 memiliki nilai residu nitrit yang besar dan mulai menurun pada perendaman hari ke-6.

Ketika nitrit ditambahkan ke dalam daging, nitrit akan bereaksi secara kimiawi atau terikat pada sejumlah komponen seperti protein. Secara teoritis, nitrat dapat diubah menjadi N-nitrosamin melalui reaksi N2O3 (berasal dari pengasaman/asidifikasi nitrit) dengan amina sekunder pada makanan (Saputro, 2016). Banyak nitrosasi dan nitrosilasi yang mempengaruhi reaksi terjadi dalam matriks daging dimana pembentukan nitrosomioglobin hal yang utama dan juga 
dapat mempengaruhi sensorik (Hammes, 2012). Menurut Soeparno (2015), penggunaan asam askorbat murni 3,5\% sudah mampu menurunkan residu nitrit pada proses curing daging. Pada penelitian ini, penggunaan ekstrak jambu biji merah sebanyak 4\% dengan lama perendaman 2 hari menghasilkan daging curing dengan karakteristik mendekati karakteristik daging sapi segar, dan residu nitrit sudah berada dibawah ambang batas yang ditetapkan oleh peraturan Kepala BPOM Nomor 36 Tahun 2013 yang membatasi kandungan nitrit sebesar $30 \mathrm{mg} / \mathrm{kg}$ pada produk daging dan olahan daging (Slamet, 2013). Hal ini karena kandungan asam askorbat dari jambu biji merah $(90,2 \mathrm{mg} / 100$ gram) lebih tinggi dari jeruk nipis dan rosella merah.

\section{KESIMPULAN}

Berdasarkan hasil penelitian semakin tinggi konsentrasi ekstrak jambu biji merah akan menyebabkan nilai $\mathrm{pH}$, kadar air, WHC, warna $b^{*}$, residu nitrit semakin kecil, sedangkan nilai hardness, springiness, cohesiveness, warna $\mathrm{L}^{*}$, warna $\mathrm{a}^{*}$, kandungan asam askorbat pada daging curing semakin besar. Perlakuan terpilih berdasar parameter pengujian terdapat pada penambahan konsentrasi ekstrak jambu biji merah pada proses curing sebanyak $4 \%$ dengan lama perendaman 2 hari.

\section{DAFTAR PUSTAKA}

[USDA] United States Departement of Agriculture. 2001. Fruit and Tree Nuts Situation and Outlook Report. United States Departement of Agriculture. USA.

'Afani, Feby Nur. 2016. Pengaruh Perbandingan Jambu Biji (Psidium guajava L.) Dengan Rosella (Hibiscus sabdariffa Linn) Dan Jenis Jambu Biji Terhadap Karakteristik Jus [Skripsi]. Bandung [ID]: Fakultas Teknik Universitas Pasundan.

Aidani, Emad., Banafsheh Aghamohammadi, Mina Akbarian, Afsaneh Morshedi, Milad Hadidi, Nila Ghasemkhani, and
Ava Akbarian. 2014. Effect Of Chilling, Freezing And Thawing On Meat Quality: A Review. International Journal of Biosciences. 5(4): 159-169.

Alvarez, Joseâ Angel Peârez., Marõâa Estrella Sayas-Barberaâ , Juana Fernaâ Ndez-Loâ Pez, and Vicente ArandaCatalaâ. 1999. Physicochemical Characteristics Of Spanish-Type DryCured Sausage. Food Research International. 32(1999): 599-607.

Astawan, Mita Wahyuni., dan Made Astawan. 1989. Teknologi Pengolahan Pangan Hewani Tepat Guna. Jakarta: CV. AKADEMIKA PRESSINDO.

Batubara, Razethy Rahayu. 2017. Perubahan Ciri Kimia Jus Buah Jambu Biji Merah Akibat Penyimpanan Dengan Waktu Dan Suhu Berbeda. Skripsi. Fakultas Matematika Dan Ilmu Pengetahuan Alam. Institut Pertanian Bogor.

Buckle, K.A., R.A.Edwards, G.H.Fleet, and M.Wootton. 1985. Ilmu Pangan. Terjemahan oleh Hadi Purnomo dan Adiono. Jakarta: UI Press.

Cassens, R. G., T. Ito, M. Lee and D. Buege. 1978. The Use of Nitrite in Meat. BioScience. 28(10): 633-637.

Chorbadzhiev, Pavel., Gabor Zsivanovits, Dilyana Gradinarska, Kamen Danov, and Katia Valkova-Jorgova. 2017. Improvement Of Texture Profile Attributes Of Cooked Sausage Type "Krenvirsh". Bulgarian Journal Of Agricultural Science. 23(2): 338-347.

Costa, Marcela De Rezende., Walter Bergamin Filho, Expedito Tadeu Facco Silveira, and Pedro Eduardo De Felício. 2008. Colour And Texture Profiles Of Boneless Reestructured Dry-Cured Hams Compared To Traditional Hams. Science Agriculture(Piracicaba, Braz.). 65(2): 169-173.

Diarmita, I. K. (2018). Statistik Peternakan

Dan Kesehatan Hewan. Jakarta: Direktorat Jendral Peternakan Dan Kesehatan Hewan (Kementrian Pertanian). 
Ermawati, Dyah. 2008. Pengaruh Penggunaan Ekstrak Jeruk Nipis (Citrus aurantifolia Swingle) Terhadap Residu Nitrit Daging Curing Selama Proses Curing. [Skripsi]. Surakarta [ID]: Universitas Sebelas Maret.

Esteban, Marta Garc1'A., Diana Ansorena, Olga Gimeno, and Iciar Astiasara'N. 2003. Optimization Of Instrumental Colour Analysis In Dry-Cured Ham. Elsevier Science Ltd' meat Science. 63(2003): 287-292.

Forrest, J. A. 1975. Principles of Meat Science. San Fransisco: W.H. Freeman and Company.

Gimeno, Olga., Diana Ansorena, Iciar Astiasaraâ N, and Joseâ Bello. 2000. Characterization Of Chorizo De Pamplona: Instrumental Measurements Of Colour And Texture. Food Chemistry. 69(2000): 195-200.

Govari M., and Pexara A. 2015. Nitrates and Nitrites in meat products. Journal of the Hellenic Veterinary Medical Society. 66(3): 127-140.

Hammes, Walter P. 2012. Metabolism of nitrate in fermented meats: The characteristic feature of a specific group of fermented foods. Food Microbiology. 29(2012): 151-156.

Honikel, Karl-Otto. 2008. The use and control of nitrate and nitrite for the processing of meat products. Meat Science. 78(2008): 68-76.

Indarto, Thomas., Putut Suseno, Sutarjo Surjoseputro, dan Ina Maria Fransisca. 2007. Pengaruh Jenis Bagian Daging Babi Dan Penambahan Tepung Terigu Terhadap Sifat Fisikomiawi Pork Nugget. Jurnal Teknologi Pangan Dan Gizi. 6(2): 15-25.

Indiarto, Rossi., Bambang Nurhadi, dan Edy Subroto. 2012. Kajian Karakteristik Tekstur (Texture Profil Analysis) Dan Organoleptik Daging Ayam Asap Berbasis Teknologi Asap Cair Tempurung Kelapa. Jurnal Teknologi Hasil Pertanian. V(2): 106-116.
Islam, R., M. M. Hossain, S. Akhter and M. A. Malek. 2009. Effect Of Curing On The Quality Of Beef And Buffen. Bangladesh Journal Animal Science. 38(1\&2): $92-101$.

Izumi, K., R. G. Cassens \& M. L. Greaser. 1989. Reaction Of Nitrite With Ascorbic Acid And Its Significant Role In Nitrite-Cured Food. Meat Science. 26(1989): 141-153.

Jading, Abadi., Nursigit Bintoro, Lilik Sutiarso, Joko Nugroho, dan Wahyu Karyadi. 2018. Pemodelan Jaringan Syaraf Tiruan untuk Memprediksi Color Difference Tepung Sagu pada Pneumatic Conveying Recirculated Dryer. Jurnal Keteknikan Pertanian. 6(2): 179-186.

Jayathilakan, K., G.K. Sharma, K. Radhakrishna, and A.S. Bawa. 2007. Antioxidant Potential Of Synthetic And Natural Antioxidants And Its Effect On Warmed-Over-Flavour In Different Species Of Meat. Food Chemistry. 105(2007): 908-916.

Karwowska, Małgorzata., and Anna Kononiuk. 2020. Nitrates/Nitrites in Food-Risk for Nitrosative Stress and Benefits. Antioxidants. 9(241): 1-17.

Kementrian Kesehatan RI. 2017. Daftar Komposisi Bahan Makanan. Bhatara Karya Aksara. Jakarta.

Kosim, A., T. Suryati, dan A. Gunawan. 2015. Sifat Fisik Dan Aktivitas Antioksidan Dendeng Daging Sapi Dengan Penambahan Stroberi (Fragaria Ananassa) Sebagai Bahan Curing. Jurnal Ilmu Produksi Dan Teknologi Hasil Peternakan. 3(3): 189-196.

Lawrie, R.A. 2003. Ilmu Daging. Diterjemahkan oleh Aminuddin Parakkasi. Jakarta: UI Press.

Mancini, R. d. (2008). Meat. Meat Science, 529.

Martinez, O., J. Salmer, M.D. Guill, and C. Casas. 2004. Texture Profile Analysis Of Meat Products Treated With 
Commercial Liquid Smoke Flavourings. Food Control. 15(2004): 457-461.

Padang, Septipianus Arung., dan Rasnita Maharani Maliku. 2017. Penetapan Kadar Vitamin C Pada Buah Jambu Biji Merah (Psidium guajava L.) Dengan Metode Titrasi Na-2,6 Dichlorophenol Indophenol (DCIP). Media Farmasi. $8(2): 1-6$

Pdpersi. (2004). Obat tradisional: Jambu biji (Psidium guajava L.). http://www.pdpersi.co.id./pusat data \& informasi PERSI.htm. Diakses: 14 Juli 2019.

Purnomo, H. d. (2013). Ilmu Pangan. Jakarta: UI Press.

Pursudarsono, Fadimas., Djalal Rosyidi, dan Aris Sri Widati. 2015. Pengaruh Perlakuan Imbangan Garam Dan Gula Terhadap Kualitas Dendeng Paru-Paru Sapi. Jurnal Ilmu Dan Teknologi Hasil Ternak. 10(1): 35-45.

Rahmawati, Yeni. 2012. Karakteristik Warna Dan Mikrobiologis Serta Palatabilitas Dendeng Sapi Yang Diberi Perlakuan Metode Curing Berbeda. Skripsi. Departemen Ilmu Produksi Dan Teknologi Peternakan. Institut Pertanian Bogor.

Ray, Frederick K. 1990. Meat Curing. Oklahoma Cooperative Extension Service. ANSI-3994: 1-4.

Rini, S. R., Sugiharto dan L. D. Mahfudz. 2019. Pengaruh Perbedaan Suhu Pemeliharaan terhadap Kualitas Fisik Daging Ayam Broiler Periode Finisher. Jurnal Sain Peternakan Indonesia. 14(4): 387-395.

Romsiah, Sintya Lara Marista, dan Ahmad Fatoni. 2017. Validasi Metode Dan Penetapan Kadar Nitrit (No2-) Pada Sosis Sapi Curah Dan Sosis Sapi Kaleng Yang Dijual Di Swalayan Kota Palembang Secara Spektrofotometri UvVis. SCIENTIA Jurnal Farmasi dan Kesehatan. 7(2): 113-119.

Samodra, E.P., Dan H. Cahyono. 2010. Kualitas Fisik Daging Sapi Peranakan
Ongole Dengan Pemberian Asam Askorbat Dan Penyimpanan Pada Suhu $50^{\circ} \mathrm{C}$. Sains Peternakan. 8(1): 26-31.

Saputro, Eko. 2016. Pemanfaatan Kyuring Alami pada Produk Daging Sapi. WARTAZOA. 26(4): 183-190.

Sarassati, Thea., dan Kadek Karang Agustina. 2015. Kualitas Daging Sapi Wagyu Dan Daging Sapi Bali Yang Disimpan Pada Suhu $-19^{\circ} \mathrm{C}$. Indonesia Medicus Veterinus. 4(3) : 178-185.

Serra, X., J. Ruiz-Ramı'Rez, J. Arnau, and P. Gou. 2005. Texture Parameters Of DryCured Ham M. Biceps Femoris Samples Dried At Different Levels As A Function Of Water Activity And Water Content. Meat Science. 69(2005): 249254.

Slamet, Lucky S., 2013. Peraturan Kepala Badan Pengawas Obat Dan Makanan Republik Indonesia Nomor 36 Tahun 2013 Tentang Batas Maksimum Penggunaan Bahan Tambahan Pangan Pengawet. Indonesia: Badan Pengawas Obat Dan Makanan Republik Indonesia.

Soeparno. 2015. Ilmu dan Teknologi Daging. Yogyakarta: UGM Press.

Sudarmadji, Slamet, Bambang Haryono dan Suhardi. 2004. Prosedur Analisa untuk Bahan Makanan dan Pertanian. Yogyakarta: Liberty.

Suradi, Kusmajadi. 2006. Perubahan Sifat Fisik Daging Ayam Broiler Post Mortem Selama Penyimpanan Temperatur Ruang. Jurnal Ilmu Ternak. 6(1): 23-27.

Szczesniak, A.S. 2002. Texture Is A Sensory Property. Food Quality And Preferences. 13: 215-225.

Tampubolon, Triana Rebecca dan Yunianta. 2017. Pengaruh Formulasi Terhadap Sifat Fisik, Kimia, Dan Organoleptik Effervescent Jambu Biji Merah (Psidium guajava var. pomifera). Jurnal Pangan dan Agroindustri. 5(3): 27-37.

Tiso, Mauro., and Alan N. Schechter. 2015. Nitrate Reduction to Nitrite, Nitric Oxide and Ammonia by Gut Bacteria 
under Physiological Conditions. PloS ONE. 10(3): 1-18.

Wijayanti, I. 2015. Karakteristik Tekstur Dan Daya Ikat Air Gel Surimi Ikan Lele Dengan Penambahan Asam Tanat Dan Ekstrak Fenol The Teroksidasi. Jurnal Saintek Perikanan. 10 (2): 84-90.

Wulan, Sekar Sari., Moh. Su'i, dan Enny Sumayati. 2019. Pengaruh Konsentrasi Garam Dan Lama Perendaman Terhadap Mutu Manisan Carica (Carica Pubescens). Jurnal Ilmu-Ilmu Pertanian “AGRIKA”. 13(1): 23-32.

Xing, Tong., Feng Gao, Ronald K. Tume, Guanghong Zhou, and Xinglian $\mathrm{Xu}$. 2018. Stress Effects on Meat Quality: A Mechanistic Perspective.

Comprehensive Reviews in Food Science and Food Safety. O0(2018): 122.

Younis, Kaiser. Rayees U Islam, Kausar Jahan, Basharat Yousuf and Aradhita
Ray. 2015. Effect of addition of mosambi (Citrus limetta) peel powder on textural and sensory properties of papaya jam. Food Science \& Technology (Cogent Food \& Agriculture). 1(2015): 1-8.

Yuniarti, Frika. 2011. Pengaruh Penggunaan Ekstrak Rosella Merah (Hibiscus Sabdariffa Linn) Dalam Berbagai Konsentrasi Terhadap Residu Nitrit Dan Pewarnaan Daging Selama Proses Curing [Skripsi]. Surakarta [ID]: Universitas Sebelas Maret.

Zulfahmi, Muhammad., 2010. Daya Ikat Air, Kadar Air, Ph Dan Organoleptik Daging Ayam Petelur Afkir Yang Direndam Dalam Ekstrak Kulit Nenas (Ananas Comosus L. Merr) Dengan Konsentrasi Yang Berbeda. Skripsi. Program Studi Peternakan Fakultas Pertanian Dan Peternakan. Universitas Islam Negeri Sultan Syarif Kasim Riau, Pekanbaru. 